\title{
Pathogenic adaptations to host-derived antibacterial copper
}

\author{
Kaveri S. Chaturvedi and Jeffrey P. Henderson* \\ Division of Infectious Diseases, Department of Internal Medicine, Center for Women's Infectious Diseases Research, Washington University School of Medicine, \\ St. Louis, MO, USA
}

Edited by:

Frédéric J. Veyrier, Institut Pasteur, France

Reviewed by:

Dennis J. Thiele, Duke University

School of Medicine, USA

James Imlay, University of Illinois at

Urbana-Champaign, USA

*Correspondence:

Jeffrey P. Henderson, Center for

Women's Infectious Disease

Research, Washington University

School of Medicine, Box 8051, 660

S. Euclid Ave., St. Louis, MO 63110 ,

USA

e-mail: jhenderson@dom.wustl.edu

Recent findings suggest that both host and pathogen manipulate copper content in infected host niches during infections. In this review, we summarize recent developments that implicate copper resistance as an important determinant of bacterial fitness at the host-pathogen interface. An essential mammalian nutrient, copper cycles between copper (I) $\left(\mathrm{Cu}^{+}\right)$in its reduced form and copper (II) $\left(\mathrm{Cu}^{2+}\right)$ in its oxidized form under physiologic conditions. $\mathrm{Cu}^{+}$is significantly more bactericidal than $\mathrm{Cu}^{2+}$ due to its ability to freely penetrate bacterial membranes and inactivate intracellular iron-sulfur clusters. Copper ions can also catalyze reactive oxygen species (ROS) generation, which may further contribute to their toxicity. Transporters, chaperones, redox proteins, receptors and transcription factors and even siderophores affect copper accumulation and distribution in both pathogenic microbes and their human hosts. This review will briefly cover evidence for copper as a mammalian antibacterial effector, the possible reasons for this toxicity, and pathogenic resistance mechanisms directed against it.

\section{Keywords: copper, pathogenesis, yersiniabactin, copper tolerance, metal biology, copper resistance}

\section{INTRODUCTION}

Copper is both an essential mammalian micronutrient and a potent antibacterial agent. The Smith Papyrus, an ancient Egyptian medical text dated at $2400 \mathrm{BC}$, is the earliest medicinal archive to recommend copper sulfate to sterilize water and treat infections (Dollwet and Sorenson, 1985). Mesoamerican and Hellenistic civilizations used copper and copper salts to treat a broad variety of physical ailments, including microbial and parasitic infections. In $400 \mathrm{BC}$, Hippocrates prescribed copper salts to treat leg ulcers. In the nineteenth century, Victor Burq observed that copper workers in Paris appeared immune to recurrent cholera epidemics (Burq, 1867). He also noted that while neighboring towns were ravaged by frequent cholera epidemics, the pottery-making town of Aubagne was protected from these outbreaks. He attributed this protection to "... a rampart of copper dust" generated by copper-rich clay used by the city's potters. These observations led to rapid developments in the field of metallotherapy, and medically employed copper salts, amulets, and belts were widely used to treat dermatologic, gastrointestinal, and tubercular infections (Dollwet and Sorenson, 1985; Borkow, 2005) until the advent of commercially available antibiotics in 1932.

Human and animal studies now suggest a parallel between ancient medicinal copper use and antibacterial immune function. In this review, we summarize copper homeostasis mechanisms in the human host, and the means by which the host deploys the metal to combat infections. We describe the chemical and biochemical principles that define copper's toxicity, and how these toxic properties serve as potent leverage against invading pathogens. Finally, we discuss the pathogenic molecular, cellular, and biochemical responses that counter copper toxicity at host interface.

\section{COPPER AS NUTRIENT OR TOXIN}

With photosynthesis and dioxygen release in the atmosphere 2.7 billion years ago, the sulfides that sequestered copper were oxidized to sulfates, leading to increased copper bioavailability (Frausto da Silva and Williams, 1993). Copper-containing proteins appeared relatively late in an evolutionary timescale, likely in response to increasing need to use oxygen and oxygen containing molecules (Dupont et al., 2011; Nevitt et al., 2012). These enzymes are critical to cellular, biochemical and regulatory functions in the human host, leading to a nutritional requirement for sufficient copper levels. The most prominent examples include cytochrome $\mathrm{c}$ oxidase, the respiratory chain terminal electron acceptor, and $\mathrm{Cu}-\mathrm{Zn}$ superoxide dismutase, required for defense against oxidative damage (Karlin, 1993). Putative copper binding proteins compose $\sim 1 \%$ of the total eukaryotic proteome, suggesting that known cuproproteins represent only a minor fraction of the total (Andreini et al., 2008). Copper's role in host biology and defense is better understood by examining its chemistry.

\section{Copper chemistry}

Copper is the 26th most abundant in the earth's crust and exists as 2 stable and 9 radioactive isotopes. A transition metal, copper primarily exists as one of two stable oxidation states: $\mathrm{Cu}^{2+}$ in the oxidized cupric form, and $\mathrm{Cu}^{+}$in the reduced cuprous form. $\mathrm{Cu}^{+}$ is a closed shell $3 \mathrm{~d}^{10}$ transition metal ion with diamagnetic properties (Frausto da Silva and Williams, 1993). A soft Lewis acid, it favors tetrahedral coordination with soft bases such as hydrides, alkyl groups, cyanide, phosphines, and thiols from cysteine and thioether bonds with methionine (Crichton and Pierre, 2001). $\mathrm{Cu}^{2+}$ has a $3 \mathrm{~d}^{9}$ configuration, is paramagnetic, and is an intermediate Lewis acid. In addition to ligands bound by $\mathrm{Cu}^{+}, \mathrm{Cu}^{2+}$ forms square planar complexes with sulphates, nitrates, nitrogen 
donors such as histidine, and oxygen donors like glutamate and aspartate (Bertini et al., 2007). Different ligand combinations, oxygenation levels, $\mathrm{pH}$, organic matter, sulfates and carbonates, generate differential metal speciation and distinct metal coordination environments. Copper's value as a bioelement lies mainly in its unique electrochemical properties. The $\mathrm{Cu}^{+} / \mathrm{Cu}^{2+}$ couple has a high redox potential, which allows it to act as an electron donor/acceptor in redox reactions (Crichton and Pierre, 2001). Most copper enzymes span a range of +200 to $+800 \mathrm{mV}$, enabling them to directly oxidize substrates such as ascorbate, catechol, and phenolates. The same electrochemical properties contribute to copper's toxic effects through several mechanisms, outlined below.

\section{Copper as a Fenton reagent}

Within superoxide and hydrogen peroxide-rich environments such as the phagosome, copper may propagate toxic hydroxyl radical formation by Fenton-like chemistry [Equation (1)] (Liochev, 1999).

$$
\mathrm{Cu}^{+}+\mathrm{H}_{2} \mathrm{O}_{2} \rightarrow \mathrm{Cu}^{2+}+\mathrm{OH}^{-}+\mathrm{OH} \bullet
$$

Hydroxyl radicals are extremely reactive, cannot be scavenged by enzymatic reaction, and have a diffusion controlled halflife of $\sim 10^{-9} \mathrm{~s}$ before reacting with organic molecules in vivo (Freinbichler et al., 2011), suggesting that hydroxyl radical damage would occur in close spatial proximity to copper ions. Extensive work has implicated reactive oxygen species (ROS) derived from metal-catalyzed oxidation in lipid, protein, and DNA oxidation (Yoshida et al., 1993; Liochev, 1999; Stadtman, 2006). Copper ions can also oxidize sulfhydryls such as cysteine or glutathione in a cycle between reactions [Equations (2), (3a,b) or $(4 \mathrm{a}, \mathrm{b})$, followed by $(\mathbf{5})]$ :

$$
\begin{gathered}
\mathrm{RSH}+\mathrm{Cu}^{2+} \rightarrow \mathrm{RS} \bullet+\mathrm{Cu}^{+}+\mathrm{H}^{+} \quad(2) \quad \text { and } \\
\mathrm{RS}+\mathrm{O}_{2} \rightarrow \mathrm{RS}^{+}+\mathrm{O}_{2}^{-} \quad(3 \mathrm{a}) \\
\mathrm{RS}^{+}+\mathrm{RSH} \rightarrow \mathrm{RSSR}+\mathrm{H}^{+} \quad(3 \mathrm{~b}) \quad \text { or } \\
\mathrm{RS} \bullet+\mathrm{RSH} \rightarrow \mathrm{RSSR}+\mathrm{H}^{+} \quad(4 \mathrm{a}) \\
\mathrm{RSSR} \bullet+\mathrm{O}_{2} \rightarrow \mathrm{RSSR}+\mathrm{O}_{2}^{-} \quad(4 \mathrm{~b}) \quad \text { followed by } \\
\mathrm{O}_{2}^{-}+\mathrm{H}^{+} \rightarrow 1 / 2 \mathrm{H}_{2} \mathrm{O}_{2}
\end{gathered}
$$

Hydrogen peroxide can in turn participate in reaction 1 and may further propagate radical formation.

Attempts to understand copper toxicity through classic copper-catalyzed Fenton chemistry to copper toxicity have produced contrary results. Macomber et al. exposed an Escherichia coli mutant with multiple copper efflux deficiencies to hydrogen peroxide (Macomber et al., 2007). Rather than exhibiting greater peroxide sensitivity [through Equation (1)], copper-loaded E. coli were instead more resistant to hydrogen peroxide. Furthermore, copper loading was associated with fewer, not more, oxidative DNA lesions. Lastly, EPR spectroscopy revealed no change in hydroxyl radical generation with copper addition. Most of the copper in overloaded strains was localized to the periplasm, where any hydroxyl radical generated would react locally before reaching
DNA in the cytoplasm. This spatial compartmentalization may explain the lack of DNA damage. While there may exist circumstances in which copper propagates cytotoxic Fenton chemistry in vivo, this work suggests the existence of an alternative copper toxicity mechanism in E. coli.

\section{Non-Fenton destruction of iron-sulfur complexes by copper}

Recent evidence suggests a non-Fenton chemistry copper toxicity mechanism in which the reduced $\mathrm{Cu}^{+}$ion is instrumental. Multiple investigators note that copper toxicity to bacteria is sustained or even enhanced in anoxic conditions (Beswick et al., 1976; Outten et al., 2001; Macomber and Imlay, 2009) where peroxide formation is minimal. Increased copper toxicity under anoxic conditions may reflect higher $\mathrm{Cu}^{+}$prevalence. E. coli EPR spectroscopy indicates that considerable $\mathrm{Cu}^{2+}$ is converted to non-paramagnetic $\mathrm{Cu}^{+}$under anoxic conditions (Beswick et al., 1976). Macomber et al. show that intracellular copper in overloaded E. coli is in the reduced $\mathrm{Cu}^{+}$valence, likely due to cytosolic reduction and its ability to enter bacteria by traversing bacterial membranes (Macomber et al., 2007). $\mathrm{Cu}^{+}$toxicity in the $E$. coli cytosol can be explained by its intense thiophilicity, which is sufficient to competitively disrupt key cytoplasmic iron-sulfur enzymes both in vitro and in vivo (Macomber and Imlay, 2009). Indeed, other "soft" thiophilic metal ions that do not act as Fenton reagents have been found to exert comparable toxicity (Jozefczak et al., 2012; Xu and Imlay, 2012). Together, these data provide compelling evidence linking copper toxicity to iron displacement from solvent-exposed dehydratase iron-sulfur clusters, resulting in metabolic disruption and branched chain amino acid auxotrophy.

\section{COPPER AT THE HOST-PATHOGEN INTERFACE}

Copper homeostasis is essential for human growth and development. Average daily human dietary copper intake varies from 0.6 to $1.6 \mathrm{mg} / \mathrm{dL}$, with a free copper ion concentration of $10^{-13} \mathrm{M}$ in human blood plasma (Linder and Hazegh-Azam, 1996). In mammalian cells, cytoplasmic metallothioneins, glutathione based redox maintenance, and the $\mathrm{Cu} / \mathrm{Zn}$ superoxide dismutase mitigate copper toxicity (Fridovich, 1974; Babula et al., 2012; Hatori et al., 2012). This section reviews the basic characteristics of human copper transporters together with data that may speak to their functions during infection and inflammation.

\section{Human copper physiology}

Unlike antimicrobial peptides, proteolytic enzymes, or ROS, copper cannot be synthesized in situ during infections and so must be absorbed from the diet or mobilized from tissue depots for use by immune cells (see a more complete review Pena et al., 1999). Once dietary copper is absorbed from the intestinal lumen it is delivered to the liver, which exports it to the peripheral circulation or excretes it into the bile (Crampton et al., 1965; Vancampen and Mitchell, 1965). The liver incorporates copper into multiple proteins, including the secreted glycosylated multi-copper ferroxidase ceruloplasmin (Holmberg and Laurell, 1948). Ceruloplasmin-copper complexes bind Ctr1, an integral membrane protein that is structurally and functionally conserved from yeast to humans (Zhou and Gitschier, 1997). Ctr1 transports $60-70 \%$ of the total copper in flux. Ctr1 is responsive to 
copper levels: copper depletion increases Ctr1 expression at the plasma membrane through the recruitment from the intracellular pools, whereas elevated copper induces rapid transporter endocytosis from the plasma membrane to vesicles (Zhou and Gitschier, 1997; Petris et al., 2003; Guo et al., 2004). Following internalization by $\mathrm{Ctr} 1$, copper is shuttled to the trans-Golgi network by ATOX1/HAH1 in secretory compartments (Klomp et al., 1997). Atox 1 gene deletion in mice results in perinatal lethality, reflecting its crucial role in normal cellular metabolism (Hamza et al., 2001). Copper is transferred directly from ATOX1 to the $\mathrm{N}$-terminus of two homologous $\mathrm{P}_{1 \mathrm{~B}}$-type ATPase $\mathrm{Cu}^{+}$transporters, ATP7A (Chelly et al., 1993; Mercer et al., 1993; Vulpe et al., 1999) and ATP7B (Bull et al., 1993; Tanzi et al., 1993; Vulpe et al., 1993), located in the trans-Golgi network. Macrophages infected with Salmonella typhimurium exhibit increased Ctr1, ATP7A and ceruloplasmin gene expression, indicating that they play a role in restricting infection by professional intracellular pathogens (Achard et al., 2012).

Copper fills varied roles in mammalian biology, and it is notable that copper-deficiency is associated with numerous deficiencies in host defense (Kaim and Rall, 1996). Mutations in ATP7A result in a severe copper-deficiency known as Menkes disease (Kaler, 2011). Infants with Menkes' disease are more susceptible to Gram-negative infections, consistent with copper's role in restricting microbial growth (Menkes et al., 1962; Danks et al., 1972; Gunn et al., 1984). Conversely, Wilson's disease is characterized by excess copper accumulation in brain and liver tissues, resulting in cirrhosis and neurodegeneration that may manifest well after infancy. Other human copper deficiency studies reveal impaired phagocytic indices, decreased antibody response, impaired peripheral mononuclear cell proliferation, lower early T-cell activation and proliferation, and lower cytokine expression (Sullivan and Ochs, 1978; Prohaska and Lukasewycz, 1990). While these conditions suggest a specialized role for copper in antibacterial immunity, caution must be taken to differentiate this from a less specific, more general nutritional role in the host (Newberne et al., 1968; Sullivan and Ochs, 1978; Boyne and Arthur, 1981; Jones and Suttle, 1983; Koller et al., 1987; Prohaska and Lukasewycz, 1990; Crocker et al., 1992; Smith et al., 2008).

\section{Copper physiology during infections}

Although incompletely understood, there are indications that a coordinated physiologic response may increase both systemic and local copper availability during infections. Compared to normal controls, copper levels increase two- to ten-fold in the serum, livers and spleens of animals infected with a range of pathogens, including viruses, bacteria, and trypanosomes (Tufft et al., 1988; Crocker et al., 1992; Matousek De Abel De La Cruz et al., 1993; Ilback et al., 2003). Increased circulating copper may be selectively imported into infected sites, as indicated by two- to five-fold increase in copper-carrier proteins (Natesha et al., 1992; Chiarla et al., 2008). X-ray microprobe analyses indicate that copper's absolute atomic concentration in area density increases a hundred-fold to several hundred micromolar within granulomatous lesions of lungs infected with Mycobacterium tuberculosis, and high copper concentrations are selectively redistributed to the exudates of wounds and burns (Beveridge et al., 1985; Jones et al.,
2001; Voruganti et al., 2005; Wagner et al., 2005). Whether this accumulation reflects uptake by myeloid cells alone or includes a tissue-wide response remains unclear.

\section{Copper as a white blood cell antibacterial agent}

In 2009, White et al. published findings from cultured macrophage-like RAW264.7 cells that are consistent with a copper-specific bactericidal system directed against phagocytosed E. coli (White et al., 2009). Phagosomal killing of K12 E. coli was greatly affected by copper content of the cell culture media. Microscopy and posttranscriptional silencing investigations linked this copper-dependent activity to ATP7A-mediated copper trafficking from the Golgi apparatus to E. coli-containing phagolysosomes. These studies suggest that in addition to its role in physiologic copper absorption, ATP7A fills a host defense function by transporting antibacterial quantities of copper ions to phagolysosomal compartments containing engulfed bacteria. Consistent with this finding, low-density lipoprotein (LDL) oxidation by macrophage-like THP-1 cells was found to be ATP7A-dependent, suggesting metal catalyzed oxidation by secreted copper ions (Qin et al., 2010). ATP7A is expressed in a broad range of both myeloid and non-myeloid cell types ( $\mathrm{La}$ Fontaine et al., 2010; Wang et al., 2011), raising the possibility that a variety of cell types may similarly direct the copper payloads to kill internalized bacteria. These observations suggest a specific functional rationale for the array of mammalian copper transport genes upregulated by proinflammatory stimuli such as interferon-gamma and lipopolysaccharide and for the altered copper physiology noted above in section Copper as a Fenton Reagent. (Achard et al., 2012). Studies to identify macrophage lineages or even non-professional phagocytes that use copper-mediated antibacterial activity would be of great interest in the area of infection biology. To date, copper-dependent uropathogenic E. coli killing has been observed in both RAW264.7 cells and mouse peritoneal macrophages (Chaturvedi et al., 2013). Altogether, these findings suggest an intriguing parallel between ancient medicinal copper use and innate immune function.

Phagosomal copper may add to, and perhaps synergize with, the diverse cellular microbial killing strategies described since Elie Metchnikoff's pioneering work on phagocytosis (Gordon, 2008). These strategies are often functionally redundant and have been broadly grouped into oxidative killing mechanisms exemplified by the macrophage respiratory burst and non-oxidative killing mechanisms such as antimicrobial peptides and hydrolytic enzymes. Interactions between copper and more established antibacterial effectors within the phagosome's restricted space are likely. Membrane permeabilizing defenses may facilitate copper entry into bacteria, while high concentrations of respiratory burst-derived oxidants are likely to modulate redox active copper ions. These interactions may be spatially and temporally governed during and after the respiratory burst. One recent finding in E. coli suggests that copper's interactions with phagosomal superoxide may greatly impact intracellular bacterial survival (see section Superoxide Dismutation).

Copper-mediated killing by vertebrate immune systems would be expected exert selective pressure on copper resistance in pathogenic bacteria. Below, we review the virulence-associated 
copper resistance systems described in several human pathogens. The classic intracellular pathogen $M$. tuberculosis upregulates genes encoding copper efflux-associated $\mathrm{P}_{1 \mathrm{~B}}$-type ATPases during macrophage infection (Ward et al., 2008; Rowland and Niederweis, 2012). Urinary E. coli isolates collected from patients with urinary tract infections (UTIs) exhibit higher growth than concomitant rectal isolates in a medium containing an inhibitory concentration of copper (Chaturvedi et al., 2012). Copper resistance genes are often observed in virulence-associated mobile genetic elements carried by E. coli as well as Legionella pneumophila, Klebsiella pneumoniae, and methicillin resistant Staphylococcus aureus (Sandegren et al., 2012; Shoeb et al., 2012; Gomez-Sanz et al., 2013; Trigui et al., 2013). E. coli and M. tuberculosis strains with engineered deficiencies in copper resistance genes exhibit impaired intracellular survival in phagocytic cells (White et al., 2009; Wolschendorf et al., 2011; Chaturvedi et al., 2013). To date, these observations suggest that resistance to copper-mediated killing among pathogens may be a virulenceassociated property driven by host innate immunity.

\section{MECHANISMS OF MICROBIAL COPPER TOLERANCE}

Copper's direct and indirect toxicity can alter enzyme specificity, disrupt cellular functions, and damage nucleic acid structure. Changes in copper concentrations during infection suggest that the host harnesses the metal's toxic properties to combat microbial growth. In response, pathogenic bacteria have evolved a series of protein- and small-molecule based defenses against copper toxicity. Unlike eukaryotic cells, most known bacterial cuproproteins are located within the cytoplasmic membrane or in the periplasmic space, perhaps to compartmentalize a potentially toxic metal species. Microbes use this copper sparingly in metabolism, and for electron transport in respiratory pathways. Given this, copper's cytoplasmic availability is tightly controlled, and data indicate that there are fewer than $10^{4}$ free copper atoms per bacterial cell, reflecting cytoplasmic copper-responsive transcriptional regulators' high copper sensitivity (Outten and O'Halloran, 2001; Changela et al., 2003; Finney and O'Halloran, 2003).

Both $\mathrm{Cu}^{+}$and $\mathrm{Cu}^{2+}$ can permeate the outer membrane of E. coli and enter the periplasm, but only $\mathrm{Cu}^{+}$is able to cross the inner membrane and reaches the cytoplasm by a currently unknown mechanism. While no copper uptake genes have yet been identified in E. coli, the outer-membrane protein ComC (under transcriptional control of the TetR-like regulator ComR) may reduce the outer membrane's copper permeability (Mermod et al., 2012). It is speculated that cytoplasmic $\mathrm{Cu}^{+}$ is largely complexed by millimolar quantities of thiols such as glutathione. Interestingly, glutathione biosynthesis gene deletion has little effect on microbial copper response, indicating that its role in detoxifying copper in bacterial cells may either be limited or redundant (Helbig et al., 2008). In this regard, qualitative and quantitative analyses of cytosolic copper binding sites in bacteria would aid our understanding of copper toxicity.

Microbial copper-resistance systems span copper efflux (cue, cus, and extrachromosomal efflux systems), copper sequestration (CusF and siderophores), and copper oxidation (mixed copper oxidases and superoxide dismutase mimics). For the sake of brevity, the following sections primarily discuss $\mathrm{Cu}^{2+}$ detection and resistance proteins that have been described in E. coli (Figure 1). Their functional homologs in other microbial species are tabulated in Table 1 (see a more complete review Rademacher and Masepohl, 2012).

\section{Copper efflux}

The cue system. In E. coli, two chromosomal systems remove excess $\mathrm{Cu}^{+}$from the cytosol (Outten et al., 2001). The cue system (for $\mathrm{Cu}$ efflux) transcriptionally activates both plasmid- and chromosomally-encoded copper homeostatic systems in response to intracellular $\mathrm{Cu}^{+}$sensing through CueR, a MerR-family metalloregulatory transcriptional activator (Petersen and Moller, 2000; Stoyanov et al., 2001). CueR coordinates one $\mathrm{Cu}^{+}$ion per monomer in an unusual and distinctive linear $\mathrm{S}-\mathrm{Cu}^{+}-\mathrm{S}$ center encompassing two cysteine residues (C112 and C120) located at the dimer interface (Changela et al., 2003; Chen et al., 2003). Both holo- and apo-CueR bind to dyad-symmetric sequences at target promoters, but only holo-CueR activates transcription (Yamamoto and Ishihama, 2005; Andoy et al., 2009). A genomewide transcriptional array study of the E. coli chromosome has identified 197 putative CueR-binding sites, which largely await experimental confirmation. Other bacteria that possess CueR-like copper-tolerance systems include Pseudomonas aeruginosa and S. typhimurium (Espariz et al., 2007; Pontel and Soncini, 2009; Thaden et al., 2010).

CueR is a copper-selective ortholog from multifunctional protein families that respond to a wide range of effector ligands (the $\mathrm{MecI} / \mathrm{BlaI}$-family repressors that mediate resistance to $\beta$-lactam antibiotics and the MerR family, respectively) (Brown et al., 2003; Portmann et al., 2006). While CueR is not widely distributed in

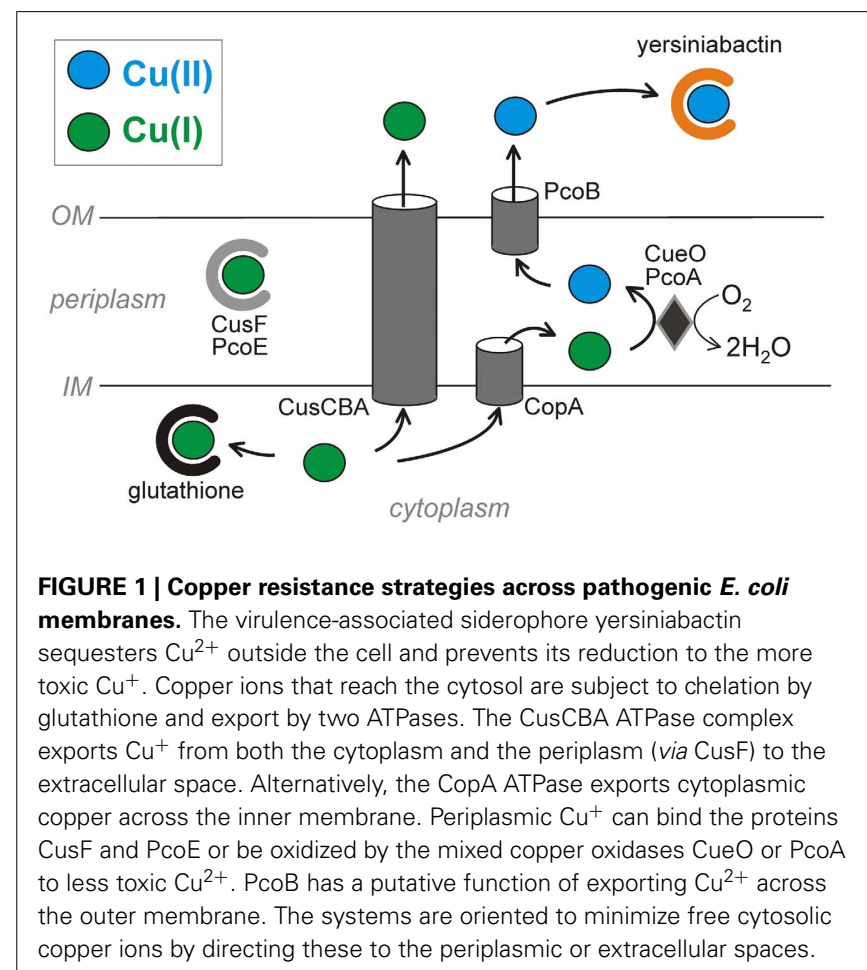


Table 1 | Species-wide distribution of copper-resistance proteins.

\begin{tabular}{|c|c|c|}
\hline Function & Protein & Species \\
\hline \multirow[t]{4}{*}{ Copper detection } & SctR GolS* & S. typhimurium (Espariz et al., 2007; Pontel et al., 2007; Osman and Cavet, 2011) \\
\hline & RicR & M. tuberculosis (Festa et al., 2011) \\
\hline & CrdRS & H. pylori (Waidner et al., 2005) \\
\hline & CopY & $\begin{array}{l}\text { Enterococcus hirae, Enterococcus faecium, Streptococcus mutans, Lactococcus lactis (Strausak and } \\
\text { Solioz, 1997; Vats and Lee, 2001; Magnani et al., 2008; Reyes-Jara et al., 2010) }\end{array}$ \\
\hline \multirow[t]{6}{*}{ Copper efflux } & GolT & S. typhimurium (Espariz et al., 2007; Osman et al., 2010) \\
\hline & CtpV & M. tuberculosis (Rowland and Niederweis, 2012) \\
\hline & CopA1 & P. aeruginosa (Thaden et al., 2010) \\
\hline & CopA2 & P. aeruginosa (Gonzalez-Guerrero et al., 2010) \\
\hline & CopA & Enterococcus hirae (Odermatt et al., 1994; Odermatt and Solioz, 1995) \\
\hline & CopB & Enterococcus hirae (Odermatt et al., 1994; Odermatt and Solioz, 1995) \\
\hline Copper oxidation & Rv0846c & M. tuberculosis (Rowland and Niederweis, 2013) \\
\hline \multirow[t]{2}{*}{ Copper homeostasis repression } & YcnK & Bacillus subtilis (Chillappagari et al., 2009) \\
\hline & CstR & Staphylococcus aureus (Grossoehme et al., 2011) \\
\hline
\end{tabular}

${ }^{*}$ Confers additional protection from gold toxicity (Espariz et al., 2007; Pontel et al., 2007).

bacterial genomes, Liu et al. describe one such copper-specific ubiquitous regulator (Liu et al., 2007). The intracellular copper sensor CsoR from M. tuberculosis is the founding member of what appears to be a large family of bacterial $\mathrm{Cu}^{+}$-responsive repressors, with greater than 170 projected members in archaeal, bacterial, and cyanobacterial genomes (Liu et al., 2007). Upon copper binding, CsoR is deactivated, leading to copper-resistance gene expression.

CueR upregulates copA and cueO gene expression (Outten et al., 2000; Stoyanov et al., 2001). These genes are associated with copper efflux and oxidation, respectively. CopA is a copperexporting $\mathrm{P}_{1 \mathrm{~B}}$-type ATPase active under high extracellular copper stress (Outten et al., 2000; Petersen and Moller, 2000; Fan and Rosen, 2002; Stoyanov et al., 2003). Mammalian and microbial $\mathrm{P}_{1 \mathrm{~B}}$-type ATPases thus perform opposing functions that determine infection outcomes. Appropriate copper import and trafficking by mammalian ATPases is required to restrict microbial growth, while copper export by microbial ATPases is necessary to withstand this toxicity. CopA traverses the inner membrane and exports $\mathrm{Cu}^{+}$from the cytosol in both oxic and anoxic conditions (Fan and Rosen, 2002; Kuhlbrandt, 2004; Arguello et al., 2007; Osman and Cavet, 2008). This efflux pump couples ATP hydrolysis to form an acylphosphate intermediate in the presence of $\mathrm{Cu}^{+}$but not $\mathrm{Cu}^{2+}$. It is speculated that two amino-terminal metal binding domains with a CXXC motif confer metal binding specificity. copA mutants in E. coli, Streptococcus pneumoniae, and Neisseria gonorrhoeae all demonstrate impaired copper efflux, intracellular metal accumulation, and increased copper sensitivity in both oxic and anoxic conditions (Rensing et al., 2000; Outten et al., 2001; Shafeeq et al., 2011; Djoko et al., 2012).
The cus system. An independent copper efflux system, the cus (for Cus ensing) system confers copper-tolerance under moderate to high copper levels in oxic conditions (Outten et al., 2001). cusRSCFBA products are believed to form a multiunit transport complex that spans the periplasmic space and is anchored in both the inner and outer membranes (Mealman et al., 2012). While CopA exports excess $\mathrm{Cu}^{+}$from the cytoplasm to the periplasm, CusRSCFBA effluxes $\mathrm{Cu}^{+}$from the periplasm (Outten et al., 2001; Franke et al., 2003; Long et al., 2010).

CusRS is a two-component regulatory system that monitors copper stress in the cell envelope and is particularly active in anoxic copper stress conditions (Munson et al., 2000). In addition to CusRS, CpxRA, and YedWV are two other previously described copper-responsive E. coli two-component regulatory systems (Yamamoto and Ishihama, 2005, 2006). CusR and CusS exhibit homology with other plasmid-borne two-component systems that are also involved in metal responsive gene regulation. Membrane bound CusS senses periplasmic $\mathrm{Cu}^{+}$, which leads to protein autophosphorylation. CusS then donates the phosphoryl group to CusR, which activates the transcription of the cusCFBA and $c u s R S$ operons. CusA belongs to the resistance-nodulationcell division (RND) proton antiporter family, CusB belongs to the membrane fusion protein family which anchor into the cytoplasmic membrane with a long periplasm-spanning domain, and CusC is an outermembrane protein with homology to the TolCstress response protein (Franke et al., 2003; Delmar et al., 2013). CusF is a periplasmic metallochaperone that binds a single atom of $\mathrm{Cu}^{+}$and participates in metal efflux by delivering the metal to CusC and CusB (Xue et al., 2008; Mealman et al., 2011).

Other prominent RND proton antiporters include the multidrug efflux systems AcrB and AcrF from E. coli, MexB from 
P. aeruginosa, and MtrD from N. gonorrhoeae (Nies and Silver, 1995; Paulsen et al., 1996). Interestingly, Cupriavidus metallidurans $\mathrm{CH} 34$ resistance to copper is attributed to RND protein expression (von Rozycki and Nies, 2009).

Extrachromosomally-encoded copper efflux systems. In environments where copper concentrations would overwhelm chromosomally encoded copper metabolic systems, microbes contain extrachromosomal loci that confer copper resistance. These loci are present in copper-resistant E. coli, Pseudomonas syringae, and Xanthomonas campestris pv. vesicatoria isolates (Tetaz and Luke, 1983; Bender and Cooksey, 1987; Brown et al., 1992; Voloudakis et al., 1993; Williams et al., 1993). All copper-resistant strains were isolated from agricultural areas characterized by repeated copper salt application as a feed additive, bactericidal agent, or antifungal agent. In these strains, the plasmid borne pco and cop operons confer copper resistance. These operons carry four related genes, $p c o A B C D R S E$ and $c o p A B C D R S$, which are expressed from chromosomal copper-inducible promoters regulated by CusRS (Brown et al., 1995; Adaikkalam and Swarup, 2005). The genes copABCDRS are arranged in two operons, copABCD and copRS, respectively. This arrangement is also found in the pco determinant but with an additional gene, $p c o E$, further downstream. Extrachromosomal systems encode two-component regulators similar to CusRS, including PcoR and PcoS from the pco operon of E. coli; CopR and CopS from the cop operon, which provides copper resistance to $P$. syringae; and SilR and SilS from the sil locus, which provides silver ion resistance to Salmonella enterica serovar Typhimurium (Gupta et al., 1999). Similar to these copper efflux systems, extrachromosomal pco system encodes PcoB and PcoD, two copper pumps that are incorporated in the outer and inner membranes, respectively (Lee et al., 2002).

Extrachromosomal resistance systems are metal oxidation state selective. Recently published PcoC spectroscopic and crystallographic data and nuclear magnetic resonance (NMR) studies of the closely related $P$. syringae protein, CopC, reveal a biologically unprecedented thioether ligation (Arnesano et al., 2003a,b; Peariso et al., 2003). PcoC can bind both $\mathrm{Cu}^{2+}$ and $\mathrm{Cu}^{+}$: the protein exhibits a cupredoxin fold that binds $\mathrm{Cu}^{+}$ through two Met sulfur atoms and one nitrogen or oxygen ligand in a hydrophobic Metrich loop that is exposed to solvent on the protein surface. $\mathrm{Cu}^{2+}$ can bind a separate site in the same protein, where it coordinates water, as well as two histidine imidazoles and two other nitrogen or oxygen ligands. Following copper sensing, microbes respond to microenvironments that contain high concentrations of unligated copper by upregulating systems associated with copper efflux, oxidation, or sequestration.

\section{Copper sequestration}

In addition to copper oxidation and efflux systems, recent studies suggest that bacteria deploy both low molecular weight proteins and small molecules to bind and sequester intracellular copper. In E. coli, the periplasmic chaperone CusF binds copper, ultimately delivering it to CusCBA for export (Franke et al., 2003; Bagai et al., 2008; Xue et al., 2008; Mealman et al., 2012). Evidence indicates that PcoE acts as a soluble copper binder in the periplasm (Zimmermann et al., 2012). Across kingdoms, metallotheioneines sequester cytoplasmic copper (Leszczyszyn et al., 2011; Thirumoorthy et al., 2011; Gumulec et al., 2012). Recent work in M. tuberculosis shows that a five-locus regulon for copper resistance is upregulated during copper stress (Festa et al., 2011). This regulon includes MymT, a cytoplasmic metallothionein that binds $\mathrm{Cu}^{+}$and attenuates copper toxicity (Gold et al., 2008). Although a native E. coli metallothionein has not yet been identified, data suggest that glutathione may exert similar cytoprotective effects by forming stable $\mathrm{Cu}^{+}$complexes (Osterberg et al., 1979; Helbig et al., 2008; Macomber and Imlay, 2009).

Some microbial siderophores, low-molecular-weight iron chelating agents, sequester copper extracellularly and protect bacteria by minimizing intracellular copper penetration. There is precedent for this among environmental bacteria that express $\mathrm{Cu}^{+}$-binding compounds (those originally identified as copper binders are called chalkophores) such as methanobactin and phytochelatin (Cervantes and Gutierrez-Corona, 1994; Rauser, 1999; Kenney and Rosenzweig, 2012). In E. coli, chemically distinct siderophore types are observed to exert opposing copper phenotypes. Specifically, the catecholate siderophore enterobactin sensitizes E. coli to copper, likely through its ability to reduce cupric ion to the more toxic cuprous ion (Grass et al., 2004). Although known as a cuprous oxidase, $\mathrm{CueO}$ prevents this interaction by directly oxidizing catechols such as dihydroxybenzoic acid, an enterobactin biosynthetic precursor (Grass et al., 2004). Conversely, phenolate siderophores such as yersiniabactin bind $\mathrm{Cu}^{2+}$ in complexes that prevent reductive free $\mathrm{Cu}^{+}$release (Chaturvedi et al., 2012). Uropathogenic E. coli strains that express yersiniabactin are protected from copper's toxic effects, suggesting that a strain's small molecule repertoire may affect its ability to survive and persist in a copper-rich environment. It is notable that yersiniabactin can protect bacteria with and without FyuA (the outer membrane ferric yersiniabactin importer) from copper toxicity, suggesting that yersiniabactin's iron uptake function does not contribute to this phenotype. Copper oxidation state selectivity among microbial small molecules is also observed in pyoverdin and pyochelin, two major siderophore types expressed by P. aeruginosa (Brandel et al., 2012). While both siderophores can bind $\mathrm{Cu}^{2+}, \mathrm{Cu}^{2+}$ supplementation upregulates genes involved in the synthesis of pyoverdin but downregulates those for pyochelin (Frangipani et al., 2008; Brandel et al., 2012). Data indicate that both siderophores prevent $\mathrm{Cu}^{2+}$ accumulation in the bacterial cell by $80 \%$ (Teitzel et al., 2006). Pyoverdin's selective expression indicates that it may play a direct role in copper tolerance, possibly by sequestering copper in reduction-resistant complexes like yersiniabactin. The chemical basis of pyoverdin's transcriptional selectivity is unclear, and response regulation is unknown. It is possible that ferric- and cupric siderophore complexes govern differential transcriptional responses.

It also remains unclear whether siderophore transport systems can discriminate between different metal bound forms. While sequestration by siderophores can attenuate copper toxicity, bacterial proteins that import siderophore-metal complexes may also play a role. The siderophore schizokinen eliminates copper's toxic effects on Anabaena (Clarke et al., 1987) but exacerbates copper toxicity in Bacillus megaterium (Arceneaux 
et al., 1984). It is possible that these differences arise from fundamental differences in metabolic and transport machinery between the two organisms. Copper schizokinen-mediated toxicity in Bacillus can be alleviated by the exogenous desferrioxamine, raising the possibility that cells transport iron to repair copper-mediated damage. This observation could be further explained by differences in each organism's ability to use its iron-uptake machinery to discriminate between cupric- and ferric-siderophore complexes. It is possible that copper indirectly affects siderophore expression by competitively inhibiting iron import or liberating intracellular iron, altering intracellular metal accumulation, and affecting a downstream biosynthetic feedback loop.

\section{Copper oxidation}

Mixed copper oxidases (MCO). $\mathrm{Cu}^{+}$is more toxic than $\mathrm{Cu}^{2+}$ when applied under anoxic conditions, as demonstrated by Macomber and Imlay (2009). Consistent with this observation, E. coli cultures treated with both $\mathrm{Cu}^{2+}$ and reductants such as ascorbate or catechols demonstrate lower viability than those treated with $\mathrm{Cu}^{2+}$ alone (Chaturvedi et al., 2012). To detoxify extracytoplasmic $\mathrm{Cu}^{+}, E$. coli use the CueR-regulated multi-copper oxidase $\mathrm{CueO}$ to oxidize toxic cuprous copper to its less toxic cupric form (Grass and Rensing, 2001; Roberts et al., 2002; Singh et al., 2004). E. coli and S. typhimurium mutants lacking CueO exhibit extreme copper sensitivity in oxic conditions. CueO contributes to $S$. typhimurium virulence in a systemic murine infection model (Achard et al., 2010). A second, plasmidborne 605 amino acid MCO called PcoA has also been described in E. coli. Periplasmic extracts containing PcoA exhibit copperinducible oxidase activity, indicating that PcoA might similarly oxidize $\mathrm{Cu}^{+}$to prevent toxicity (Huffman et al., 2002; Djoko et al., 2008). PcoA can functionally substitute for CueO in E. coli, indicating that these proteins have redundant function.

E. coli CueO is among the best-characterized bacterial multicopper oxidases (MCOs). CueO is structurally similar to the large, cross-Kingdom family of MCOs [including ascorbate oxidase and the ferroxidases Fet3 and ceruloplasmin (Outten et al., 2000)] that oxidize substrates using oxidizing equivalents in molecular oxygen. This oxygen requirement renders oxidases inactive under anoxic conditions. CueO's active site consists of a trinuclear copper center MCO active site in which a fourth copper atom mediates electron transfer from the substrate (Roberts et al., 2002; Grass et al., 2004). The enzyme couples $\mathrm{Cu}^{+}$oxidation with four-electron oxygen oxidation to water through the hydroxide-bridged fourth copper atom. Reactive oxygen intermediates generated during the reaction remain coordinated and are not released from the protein. It is curious that despite low cytoplasmic copper levels, CueO and PcoA exhibit a twin-arginine motif in their leader sequences, suggesting that they are translocated from the cytoplasm by the twin arginine translocation (Tat) pathway with copper-bound active sites (Huffman et al., 2002). Holo-protein translocation from the cytoplasm means that some amount of chaperonebound copper must be delivered to these apo-proteins intracellularly. This indicates that intracellular copper may serve a biosynthetic role in this specific process. If MCOs ultimately evolved to prevent copper entry to the cytosol, it is possible that metallation by cytosolic copper is a form of feedback regulation in which higher cytosolic copper levels lead to higher MCO secretion. Further studies are necessary to discern this, and other, possibilities.

In addition to oxidizing periplasmic $\mathrm{Cu}^{+}, E$. coli $\mathrm{CueO}$ can also oxidize 2,3 dihydrobenzoic acid (DHB) (Grass et al., 2004). 2,3-DHB is the biosynthetic precursor to enterobactin, a catecholate siderophore, secreted during iron limitation. As enterobactin can reduce $\mathrm{Cu}^{2+}$ to $\mathrm{Cu}^{+}$, it has been hypothesized that CueO's 2,3-DHB oxidation activity is a strategy to prevent toxic $\mathrm{Cu}^{+}$accumulation. While it may seem paradoxical to both synthesize and destroy a siderophore, an intracellular copper requirement for $\mathrm{CueO}$ secretion may ensure that it's siderophore destructive activity is only relevant in the presence of high copper levels. Together, these findings suggest that MCO's such as CueO help protect bacteria from copper stress by controlling copper ion oxidation states in oxic environments.

Superoxide dismutation. Recent work shows that yersiniabactin expression greatly facilitates pathogen survival within phagocytic cells in a copper- and NADPH oxidase system-dependent manner (Chaturvedi et al., 2013). In the presence of copper- and NADPH oxidase-derived superoxide, yersiniabactin production protects urinary pathogenic E. coli within cultured macrophagelike cell phagosomes. Superoxide's contribution to this phenotype suggests that yersiniabactin's cytoprotective effects may not be attributable to copper sequestration alone. Subsequent biochemical characterizations reveal that the copper-yersiniabactin complexes catalyze superoxide dismutation according to [Equations (6) and (7)]:

$$
\begin{aligned}
& \mathrm{O}_{2} \bullet^{-}+\mathrm{Cu}^{2+}-\mathrm{Ybt} \rightarrow \mathrm{Cu}^{+}-\mathrm{Ybt}+\mathrm{O}_{2} \\
& \mathrm{O}_{2} \bullet^{-}+\mathrm{Cu}^{+}-\mathrm{Ybt}+2 \mathrm{H}^{+} \rightarrow \mathrm{Cu}^{2+}-\mathrm{Ybt}+\mathrm{H}_{2} \mathrm{O}_{2}
\end{aligned}
$$

Copper-yersiniabactin confined within the phagolysosome may thus greatly diminish concentrations of superoxide (a reductant), while maintaining or increasing production of hydrogen peroxide (an oxidant). This may have the effect of minimizing reduced $\mathrm{Cu}^{+}$concentrations while increasing oxidized-and less toxic- $\mathrm{Cu}^{2+}$ ion concentrations. Periplasmic $\mathrm{Cu}, \mathrm{Zn}-\mathrm{SOD}$ may similarly protect against copper stress, although there are distinctive pathogenic advantages to deploying a nonprotein catalyst such as copper-yersiniabactin in the phagosomal microenvironment (Chaturvedi et al., 2013). Yersiniabactin may synergize with $\mathrm{CueO}$ and other mixed copper oxidases by binding $\mathrm{Cu}^{2+}$ product ions generated by these enzymes to form catalytic copper-yersiniabactin. While interactions such as these will require further experimental validation, they fit with an overall paradigm in which pathogens appear able to convert hostsupplied copper into catalysts (mixed copper oxidases, copperyersiniabactin, $\mathrm{Cu}, \mathrm{Zn}-\mathrm{SOD}$ ) that help resist copper toxicity. SOD activity may promote bacterial survival in several pathologically important host niches and its connection with copper suggests new insights into host defense mechanisms that are critical to infection pathogenesis. 


\section{PROSPECTS}

Much remains to be understood about the mechanisms by which mammalian hosts deploy copper to resist infection, and how pathogenic bacteria respond to these strategies. ATP7A's emerging role in direct antibacterial immunity warrants its detailed study in mammalian cells that encounter bacterial pathogens. Cell type, pathogen, and regulatory activity may result in unforeseen interactions between copper and other innate immune effector molecules. Possible cooperation with mammalian copper absorption and trafficking may suggest routes by which copper-based immunity could be therapeutically supported. Both basic and translational research efforts will be necessary to understand these details.

The mechanisms by which pathogenic bacteria resist copper during mammalian infections merits further investigation. Studies conducted in bacterial cultures with environmental and pathogenic isolates provide an excellent starting point for infection models that may provide additional insights. The recent finding that yersiniabactin, a virulence-associated siderophore in E. coli binds copper during humans infections (Chaturvedi et al., 2012) and promotes microbial survival in phagocytic cells suggests that host microenvironments may reveal new copper resistance strategies (Chaturvedi et al., 2013). Yersiniabactin exemplifies the rich array of microbial secondary compounds that may include other copper-detoxifying microbial products. Metabolomic approaches, which are sensitive to the end products of multi-gene biosynthetic units, are well suited to discover additional copper-binding secondary compounds.

Copper's inherent toxicity has renewed interest in its use as an antimicrobial. Three hundred different copper and copper alloy surfaces are registered with the U.S. Environmental Protection Agency as antimicrobials and trials are underway to determine whether copper treated surfaces can significantly reduce nosocomial infections (http://www.epa.gov/pesticides/factsheets/ copper-alloy-products.htm) (Grass et al., 2011). While these approaches may be useful in limiting nosocomial infections, it is worth noting that environmental copper-resistance loci have been isolated from Gram-negative bacteria that colonize agricultural areas repeatedly treated with copper salts. Given the linkage between copper resistance and virulence, it would be worth knowing whether sublethal copper exposures might effectively select for increased virulence in bacteria. Improved insight into bacterial copper resistance mechanisms in vivo and in environmental settings will be necessary to optimize antimicrobial uses of copper.

\section{REFERENCES}

Achard, M. E., Stafford, S. L., Bokil, N. J., Chartres, J., Bernhardt, P. V., Schembri, M. A., et al. (2012). Copper redistribution in murine macrophages in response to Salmonella infection. Biochem. J. 444, 51-57. doi: 10.1042/BJ20112180

Achard, M. E., Tree, J. J., Holden, J. A., Simpfendorfer, K. R., Wijburg, O. L., Strugnell, R. A., et al. (2010). The multi-copper-ion oxidase CueO of Salmonella enterica serovar Typhimurium is required for systemic virulence. Infect. Immun. 78, 2312-2319. doi: 10.1128/IAI.01208-09

Adaikkalam, V., and Swarup, S. (2005). Characterization of copABCD operon from a copper-sensitive Pseudomonas putida strain. Can. J. Microbiol. 51, 209-216. doi: 10.1139/w04-135

Andoy, N. M., Sarkar, S. K., Wang, Q., Panda, D., Benitez, J. J., Kalininskiy, A., et al. (2009). Single-molecule study of metalloregulator CueR-DNA interactions using engineered Holliday junctions. Biophys. J. 97, 844-852. doi: 10.1016/j.bpj.2009.05.027

Andreini, C., Banci, L., Bertini, I., and Rosato, A. (2008). Occurrence of copper proteins through the three domains of life: a bioinformatic approach. J. Proteome Res. 7, 209-216. doi: 10.1021/pr070480u

Arceneaux, J. E., Boutwell, M. E., and Byers, B. R. (1984). Enhancement of copper toxicity by siderophores in Bacillus megaterium. Antimicrob. Agents Chemother. 25, 650-652. doi: 10.1128/AAC.25.5.650

Arguello, J. M., Eren, E., and Gonzalez-Guerrero, M. (2007). The structure and function of heavy metal transport P1B-ATPases. Biometals 20, 233-248. doi: 10.1007/s10534-006-9055-6

Arnesano, F., Banci, L., Bertini, I., Felli, I. C., Luchinat, C., and Thompsett, A. R. (2003a). A strategy for the NMR characterization of type II copper(II) proteins: the case of the copper trafficking protein CopC from Pseudomonas syringae. J. Am. Chem. Soc. 125, 7200-7208. doi: 10.1021/ja034112c

Arnesano, F., Banci, L., Bertini, I., Mangani, S., and Thompsett, A. R. (2003b). A redox switch in CopC: an intriguing copper trafficking protein that binds copper(I) and copper(II) at different sites. Proc. Natl. Acad. Sci. U.S.A. 100, 3814-3819. doi: 10.1073/pnas.0636904100

Babula, P., Masarik, M., Adam, V., Eckschlager, T., Stiborova, M., Trnkova, L., et al. (2012). Mammalian metallothioneins: properties and functions. Metallomics 4, 739-750. doi: 10.1039/c2mt20081c

Bagai, I., Rensing, C., Blackburn, N. J., and McEvoy, M. M. (2008). Direct metal transfer between periplasmic proteins identifies a bacterial copper chaperone. Biochemistry 47, 11408-11414. doi: 10.1021/bi801638m

Bender, C. L., and Cooksey, D. A. (1987). Molecular cloning of copper resistance genes from Pseudomonas syringae pv. tomato. J. Bacteriol. 169, 470-474.

Bertini, I., Gray, H., Steifel, E., and Valentine, J. S. (2007). Biological Inorganic Chemistry: Structure and Reactivity, Sausalito, CA: University Science Books.

Beswick, P. H., Hall, G. H., Hook, A. J., Little, K., McBrien, D. C., and Lott, K. A. (1976). Copper toxicity: evidence for the conversion of cupric to cuprous copper in vivo under anaerobic conditions. Chem. Biol. Interact. 14, 347-356. doi: 10.1016/0009-2797(76)90113-7

Beveridge, S. J., Garrett, I. R., Whitehouse, M. W., Vernon-Roberts, B., and Brooks, P. M. (1985). Biodistribution of $64 \mathrm{Cu}$ in inflamed rats following administration of two anti-inflammatory copper complexes. Agents Actions 17, 104-111. doi: 10.1007/BF01966692

Borkow, G. (2005). Copper as a biocidal tool. Curr. Med. Chem. 12, 2163-2175. doi: $10.2174 / 0929867054637617$

Boyne, R., and Arthur, J. R. (1981). Effects of selenium and copper deficiency on neutrophil function in cattle. J. Comp. Pathol. 91, 271-276. doi: 10.1016/00219975(81)90032-3

Brandel, J., Humbert, N., Elhabiri, M., Schalk, I. J., Mislin, G. L., and Albrecht-Gary, A. M. (2012). Pyochelin, a siderophore of Pseudomonas aeruginosa: physicochemical characterization of the iron(III), copper(II) and zinc(II) complexes. Dalton Trans. 41, 2820-2834. doi: 10.1039/c1dt11804h

Brown, N. L., Barrett, S. R., Camakaris, J., Lee, B. T., and Rouch, D. A. (1995). Molecular genetics and transport analysis of the copper-resistance determinant (pco) from Escherichia coli plasmid pRJ1004. Mol. Microbiol. 17, 1153-1166. doi: 10.1111/j.1365-2958.1995.mmi_17061153.x

Brown, N. L., Rouch, D. A., and Lee, B. T. (1992). Copper resistance determinants in bacteria. Plasmid 27, 41-51. doi: 10.1016/0147-619X(92)90005-U

Brown, N. L., Stoyanov, J. V., Kidd, S. P., and Hobman, J. L. (2003). The MerR family of transcriptional regulators. FEMS Microbiol. Rev. 27, 145-163. doi: 10.1016/S0168-6445(03)00051-2

Bull, P. C., Thomas, G. R., Rommens, J. M., Forbes, J. R., and Cox, D. W. (1993). The Wilson disease gene is a putative copper transporting P-type ATPase similar to the Menkes gene. Nat. Genet. 5, 327-337. doi: 10.1038/ng1293-327

Burq, V. (1867). Du cuivre contre le cholera: de l'immunite acquise par les ouvriers en cuivre par rapport au Cholera. Paris: G. Bailiere.

Cervantes, C., and Gutierrez-Corona, F. (1994). Copper resistance mechanisms in bacteria and fungi. FEMS Microbiol. Rev. 14, 121-137. doi: 10.1111/j.15746976.1994.tb00083.x

Changela, A., Chen, K., Xue, Y., Holschen, J., Outten, C. E., O’Halloran, T. V., et al. (2003). Molecular basis of metal-ion selectivity and zeptomolar sensitivity by CueR. Science 301, 1383-1387. doi: 10.1126/science.1085950

Chaturvedi, K. S., Hung, C. S., Crowley, J. R., Stapleton, A. E., and Henderson, J. P. (2012). The siderophore yersiniabactin binds copper to protect pathogens during infection. Nat. Chem. Biol. 8, 731-736. doi: 10.1038/nchembio.1020 
Chaturvedi, K. S., Hung, C. S., Giblin, D. E., Urushidani, S., Austin, A. M., Dinauer, M. C., et al. (2013). Cupric yersiniabactin is a virulence-associated superoxide dismutase mimic. ACS Chem. Biol. doi: 10.1021/cb400658k. [Epub ahead of print].

Chelly, J., Tumer, Z., Tonnesen, T., Petterson, A., Ishikawa-Brush, Y., Tommerup, N., et al. (1993). Isolation of a candidate gene for Menkes disease that encodes a potential heavy metal binding protein. Nat. Genet. 3, 14-19. doi: 10.1038/ng0193-14

Chen, K., Yuldasheva, S., Penner-Hahn, J. E., and O'Halloran, T. V. (2003). An atypical linear $\mathrm{Cu}(\mathrm{I})$-S2 center constitutes the high-affinity metal-sensing site in the CueR metalloregulatory protein. J. Am. Chem. Soc. 125, 12088-12089. doi: $10.1021 /$ ja036070y

Chiarla, C., Giovannini, I., and Siegel, J. H. (2008). Patterns of correlation of plasma ceruloplasmin in sepsis. J. Surg. Res. 144, 107-110. doi: 10.1016/j.jss.2007.03.024

Chillappagari, S., Miethke, M., Trip, H., Kuipers, O. P., and Marahiel, M. A. (2009). Copper acquisition is mediated by $\mathrm{YcnJ}$ and regulated by $\mathrm{YcnK}$ and $\mathrm{CsoR}$ in Bacillus subtilis. J. Bacteriol. 191, 2362-2370. doi: 10.1128/JB.01616-08

Clarke, S. E., Stuart, J., and Sanders-Loehr, J. (1987). Induction of siderophore activity in Anabaena spp. and its moderation of copper toxicity. Appl. Environ. Microbiol. 53, 917-922.

Crampton, R. F., Matthews, D. M., and Poisner, R. (1965). Observations on the mechanism of absorption of copper by the small intestine. J. Physiol. 178, 111-126.

Crichton, R. R., and Pierre, J. L. (2001). Old iron, young copper: from Mars to Venus. Biometals 14, 99-112. doi: 10.1023/A:1016710810701

Crocker, A., Lee, C., Aboko-Cole, G., and Durham, C. (1992). Interaction of nutrition and infection: effect of copper deficiency on resistance to Trypanosoma lewisi. J. Natl. Med. Assoc. 84, 697-706.

Danks, D. M., Campbell, P. E., Walker-Smith, J., Stevens, B. J., Gillespie, J. M., Blomfield, J., et al. (1972). Menkes' kinky-hair syndrome. Lancet 1, 1100-1102. doi: 10.1016/S0140-6736(72)91433-X

Delmar, J. A., Su, C. C., and Yu, E. W. (2013). Structural mechanisms of heavy-metal extrusion by the Cus efflux system. Biometals 26, 593-607. doi: 10.1007/s10534-013-9628-0

Djoko, K. Y., Franiek, J. A., Edwards, J. L., Falsetta, M. L., Kidd, S. P., Potter, A. J., et al. (2012). Phenotypic characterization of a copA mutant of Neisseria gonorrhoeae identifies a link between copper and nitrosative stress. Infect. Immun. 80, 1065-1071. doi: 10.1128/IAI.06163-11

Djoko, K. Y., Xiao, Z., and Wedd, A. G. (2008). Copper resistance in E. coli: the multicopper oxidase PcoA catalyzes oxidation of copper(I) in $\mathrm{Cu}(\mathrm{I}) \mathrm{Cu}(\mathrm{II})-\mathrm{PcoC}$. Chembiochem 9, 1579-1582. doi: 10.1002/cbic.200800100

Dollwet, H., and Sorenson, J. R. J. (1985). Historic uses of copper compounds in medicine. Trace Elem. Med. 2, 80-87.

Dupont, C. L., Grass, G., and Rensing, C. (2011). Copper toxicity and the origin of bacterial resistance-new insights and applications. Metallomics 3, 1109-1118. doi: 10.1039/clmt00107h

Espariz, M., Checa, S. K., Audero, M. E., Pontel, L. B., and Soncini, F. C. (2007). Dissecting the Salmonella response to copper. Microbiology 153, 2989-2997. doi: 10.1099/mic.0.2007/006536-0

Fan, B., and Rosen, B. P. (2002). Biochemical characterization of CopA, the Escherichia coli $\mathrm{Cu}(\mathrm{I})$-translocating P-type ATPase. J. Biol. Chem. 277, 46987-46992. doi: 10.1074/jbc.M208490200

Festa, R. A., Jones, M. B., Butler-Wu, S., Sinsimer, D., Gerads, R., Bishai, W. R., et al. (2011). A novel copper-responsive regulon in Mycobacterium tuberculosis. Mol. Microbiol. 79, 133-148. doi: 10.1111/j.1365-2958.2010.07431.x

Finney, L. A., and O'Halloran, T. V. (2003). Transition metal speciation in the cell: insights from the chemistry of metal ion receptors. Science 300, 931-936. doi: 10.1126/science.1085049

Frangipani, E., Slaveykova, V. I., Reimmann, C., and Haas, D. (2008). Adaptation of aerobically growing Pseudomonas aeruginosa to copper starvation. J. Bacteriol. 190, 6706-6717. doi: 10.1128/JB.00450-08

Franke, S., Grass, G., Rensing, C., and Nies, D. H. (2003). Molecular analysis of the copper-transporting efflux system CusCFBA of Escherichia coli. J. Bacteriol. 185, 3804-3812. doi: 10.1128/JB.185.13.3804-3812.2003

Frausto da Silva, J. J. R., and Williams, R. (1993). The Biological Chemistry of the Elements: The Inorganic Chemistry of Life. Oxford: Oxford University Press.

Freinbichler, W., Colivicchi, M. A., Stefanini, C., Bianchi, L., Ballini, C., Misini, B., et al. (2011). Highly reactive oxygen species: detection, formation, and possible functions. Cell. Mol. Life Sci. 68, 2067-2079. doi: 10.1007/s00018-011-0682-x
Fridovich, I. (1974). Superoxide dismutases. Adv. Enzymol. Relat. Areas Mol. Biol. 41, 35-97.

Gold, B., Deng, H., Bryk, R., Vargas, D., Eliezer, D., Roberts, J., et al. (2008). Identification of a copper-binding metallothionein in pathogenic mycobacteria. Nat. Chem. Biol. 4, 609-616. doi: 10.1038/nchembio.109

Gomez-Sanz, E., Kadlec, K., Fessler, A. T., Zarazaga, M., Torres, C., and Schwarz, S. (2013). Novel erm(T)-carrying multiresistance plasmids from porcine and human isolates of methicillin-resistant Staphylococcus aureus ST398 that also harbor cadmium and copper resistance determinants. Antimicrob. Agents Chemother. 57, 3275-3282. doi: 10.1128/AAC.00171-13

Gonzalez-Guerrero, M., Raimunda, D., Cheng, X., and Arguello, J. M. (2010). Distinct functional roles of homologous $\mathrm{Cu}+$ efflux ATPases in Pseudomonas aeruginosa. Mol. Microbiol. 78, 1246-1258. doi: 10.1111/j.13652958.2010.07402.x

Gordon, S. (2008). Elie Metchnikoff: father of natural immunity. Eur. J. Immunol. 38, 3257-3264. doi: 10.1002/eji.200838855

Grass, G., and Rensing, C. (2001). CueO is a multi-copper oxidase that confers copper tolerance in Escherichia coli. Biochem. Biophys. Res. Commun. 286, 902-908. doi: 10.1006/bbrc.2001.5474

Grass, G., Rensing, C., and Solioz, M. (2011). Metallic copper as an antimicrobial surface. Appl. Environ. Microbiol. 77, 1541-1547. doi: 10.1128/AEM.02766-10

Grass, G., Thakali, K., Klebba, P. E., Thieme, D., Muller, A., Wildner, G. F., et al. (2004). Linkage between catecholate siderophores and the multicopper oxidase $\mathrm{CueO}$ in Escherichia coli. J. Bacteriol. 186, 5826-5833. doi: 10.1128/JB.186.17.5826-5833.2004

Grossoehme, N., Kehl-Fie, T. E., Ma, Z., Adams, K. W., Cowart, D. M., Scott, R. A., et al. (2011). Control of copper resistance and inorganic sulfur metabolism by paralogous regulators in Staphylococcus aureus. J. Biol. Chem. 286, 13522-13531. doi: 10.1074/jbc.M111.220012

Gumulec, J., Masarik, M., Krizkova, S., Hlavna, M., Babula, P., Hrabec, R., et al. (2012). Evaluation of alpha-methylacyl-CoA racemase, metallothionein and prostate specific antigen as prostate cancer prognostic markers. Neoplasma 59, 191-201. doi: 10.4149/neo_2012_025

Gunn, T. R., MacFarlane, S., and Phillips, L. I. (1984). Difficulties in the neonatal diagnosis of Menkes' kinky hair syndrome-trichopoliodystrophy. Clin. Pediatr. 23, 514-516. doi: 10.1177/000992288402300915

Guo, Y., Smith, K., Lee, J., Thiele, D. J., and Petris, M. J. (2004). Identification of methionine-rich clusters that regulate copper-stimulated endocytosis of the human Ctr1 copper transporter. J. Biol. Chem. 279, 17428-17433. doi: 10.1074/jbc.M401493200

Gupta, A., Matsui, K., Lo, J. F., and Silver, S. (1999). Molecular basis for resistance to silver cations in Salmonella. Nat. Med. 5, 183-188. doi: 10.1038/5545

Hamza, I., Faisst, A., Prohaska, J., Chen, J., Gruss, P., and Gitlin, J. D. (2001). The metallochaperone Atoxl plays a critical role in perinatal copper homeostasis. Proc. Natl. Acad. Sci. U.S.A. 98, 6848-6852. doi: 10.1073/pnas. 111058498

Hatori, Y., Clasen, S., Hasan, N. M., Barry, A. N., and Lutsenko, S. (2012). Functional partnership of the copper export machinery and glutathione balance in human cells. J. Biol. Chem. 287, 26678-26687. doi: 10.1074/jbc.M112.381178

Helbig, K., Bleuel, C., Krauss, G. J., and Nies, D. H. (2008). Glutathione and transition-metal homeostasis in Escherichia coli. J. Bacteriol. 190, 5431-5438. doi: 10.1128/JB.00271-08

Holmberg, C. G., and Laurell, C. B. (1948). Investigations in serum copper. II. Isolation of the copper containing protein and a description of some of its properties. Acta Chem. Scand. 2, 550-556. doi: 10.3891/acta.chem.scand.02-0550

Huffman, D. L., Huyett, J., Outten, F. W., Doan, P. E., Finney, L. A., Hoffman, B. M., et al. (2002). Spectroscopy of $\mathrm{Cu}(\mathrm{II})-\mathrm{PcoC}$ and the multicopper oxidase function of PcoA, two essential components of Escherichia coli pco copper resistance operon. Biochemistry 41, 10046-10055. doi: 10.1021/ bi0259960

Ilback, N. G., Benyamin, G., Lindh, U., and Friman, G. (2003). Sequential changes in $\mathrm{Fe}, \mathrm{Cu}$, and $\mathrm{Zn}$ in target organs during early Coxsackievirus B3 infection in mice. Biol. Trace Elem. Res. 91, 111-124. doi: 10.1385/BTER:91:2:111

Jones, D. G., and Suttle, N. F. (1983). The effect of copper deficiency on the resistance of mice to infection with Pasteurella haemolytica. J. Comp. Pathol. 93, 143-149. doi: 10.1016/0021-9975(83)90052-X

Jones, P. W., Taylor, D., Williams, D. R., Finney, M., Iorwerth, A., Webster, D., et al. (2001). Using wound fluid analyses to identify trace element requirements for efficient healing. J. Wound Care 10, 205-208. 
Jozefczak, M., Remans, T., Vangronsveld, J., and Cuypers, A. (2012). Glutathione is a key player in metal-induced oxidative stress defenses. Int. J. Mol. Sci. 13, 3145-3175. doi: 10.3390/ijms13033145

Kaim, W., and Rall, J. (1996). Copper-a 'modern' bioelement. Angew. Chem. Int. Ed. Engl. 35, 43-60. doi: 10.1002/anie.199600431

Kaler, S. G. (2011). ATP7A-related copper transport diseases-emerging concepts and future trends. Nat. Rev. Neurol. 7, 15-29. doi: 10.1038/nrneurol.2010.180

Karlin, K. D. (1993). Metalloenzymes, structural motifs, and inorganic models. Science 261, 701-708. doi: 10.1126/science.7688141

Kenney, G. E., and Rosenzweig, A. C. (2012). Chemistry and biology of the copper chelator methanobactin. ACS Chem. Biol. 7, 260-268. doi: 10.1021/cb2003913

Klomp, L. W., Lin, S. J., Yuan, D. S., Klausner, R. D., Culotta, V. C., and Gitlin, J. D. (1997). Identification and functional expression of HAH1, a novel human gene involved in copper homeostasis. J. Biol. Chem. 272, 9221-9226. doi $10.1074 /$ jbc.272.14.9221

Koller, L. D., Mulhern, S. A., Frankel, N. C., Steven, M. G., and Williams, J. R. (1987). Immune dysfunction in rats fed a diet deficient in copper. Am. J. Clin. Nutr. 45, 997-1006.

Kuhlbrandt, W. (2004). Biology, structure and mechanism of P-type ATPases. Nat. Rev. Mol. Cell Biol. 5, 282-295. doi: 10.1038/nrm1354

La Fontaine, S., Ackland, M. L., and Mercer, J. F. (2010). Mammalian coppertransporting P-type ATPases, ATP7A and ATP7B: emerging roles. Int. J. Biochem. Cell Biol. 42, 206-209. doi: 10.1016/j.biocel.2009.11.007

Lee, S. M., Grass, G., Rensing, C., Barrett, S. R., Yates, C. J., Stoyanov, J. V., et al. (2002). The Pco proteins are involved in periplasmic copper handling in Escherichia coli. Biochem. Biophys. Res. Commun. 295, 616-620. doi: 10.1016/S0006-291X(02)00726-X

Leszczyszyn, O. I., Zeitoun-Ghandour, S., Sturzenbaum, S. R., and Blindauer, C. A. (2011). Tools for metal ion sorting: in vitro evidence for partitioning of zinc and cadmium in C. elegans metallothionein isoforms. Chem. Commun. 47, 448-450. doi: $10.1039 / \mathrm{c} 0 \mathrm{cc} 02188 \mathrm{a}$

Linder, M. C., and Hazegh-Azam, M. (1996). Copper biochemistry and molecular biology. Am. J. Clin. Nutr. 63, 797S-811S.

Liochev, S. I. (1999). The mechanism of "Fenton-like" reactions and their importance for biological systems. A biologist's view. Met. Ions Biol. Syst. 36, 1-39.

Liu, T., Ramesh, A., Ma, Z., Ward, S. K., Zhang, L., George, G. N., et al. (2007). CsoR is a novel Mycobacterium tuberculosis copper-sensing transcriptional regulator. Nat. Chem. Biol. 3, 60-68. doi: 10.1038/nchembio844

Long, F., Su, C. C., Zimmermann, M. T., Boyken, S. E., Rajashankar, K. R., Jernigan, R. L., et al. (2010). Crystal structures of the CusA efflux pump suggest methionine-mediated metal transport. Nature 467, 484-488. doi: 10.1038/nature09395

Macomber, L., and Imlay, J. A. (2009). The iron-sulfur clusters of dehydratases are primary intracellular targets of copper toxicity. Proc. Natl. Acad. Sci. U.S.A. 106 8344-8349. doi: 10.1073/pnas.0812808106

Macomber, L., Rensing, C., and Imlay, J. A. (2007). Intracellular copper does not catalyze the formation of oxidative DNA damage in Escherichia coli. J. Bacteriol. 189, 1616-1626. doi: 10.1128/JB.01357-06

Magnani, D., Barre, O., Gerber, S. D., and Solioz, M. (2008). Characterization of the CopR regulon of Lactococcus lactis IL1403. J. Bacteriol. 190, 536-545. doi: 10.1128/JB.01481-07

Matousek De Abel De La Cruz, A. J., Burguera, J. L., Burguera, M., and Anez, N. (1993). Changes in the total content of iron, copper, and zinc in serum, heart, liver, spleen, and skeletal muscle tissues of rats infected with Trypanosoma cruzi. Biol. Trace Elem. Res. 37, 51-70. doi: 10.1007/ BF02789401

Mealman, T. D., Bagai, I., Singh, P., Goodlett, D. R., Rensing, C., Zhou, H., et al. (2011). Interactions between CusF and CusB identified by NMR spectroscopy and chemical cross-linking coupled to mass spectrometry. Biochemistry 50, 2559-2566. doi: 10.1021/bi102012j

Mealman, T. D., Blackburn, N. J., and McEvoy, M. M. (2012). Metal export by CusCFBA, the periplasmic $\mathrm{Cu}(\mathrm{I}) / \mathrm{Ag}(\mathrm{I})$ transport system of Escherichia coli. Curr. Top. Membr. 69, 163-196. doi: 10.1016/B978-0-12-394390-3.00007-0

Menkes, J. H., Alter, M., Steigleder, G. K., Weakley, D. R., and Sung, J. H. (1962). A sex-linked recessive disorder with retardation of growth, peculiar hair, and focal cerebral and cerebellar degeneration. Pediatrics 29, 764-779.

Mercer, J. F., Livingston, J., Hall, B., Paynter, J. A., Begy, C., Chandrasekharappa, S., et al. (1993). Isolation of a partial candidate gene for Menkes disease by positional cloning. Nat. Genet. 3, 20-25. doi: 10.1038/ng0193-20
Mermod, M., Magnani, D., Solioz, M., and Stoyanov, J. V. (2012). The copperinducible ComR (YcfQ) repressor regulates expression of ComC (YcfR), which affects copper permeability of the outer membrane of Escherichia coli. Biometals 25, 33-43. doi: 10.1007/s10534-011-9510-x

Munson, G. P., Lam, D. L., Outten, F. W., and O'Halloran, T. V. (2000). Identification of a copper-responsive two-component system on the chromosome of Escherichia coli K-12. J. Bacteriol. 182, 5864-5871. doi: 10.1128/JB.182.20.5864-5871.2000

Natesha, R. K., Natesha, R., Victory, D., Barnwell, S. P., and Hoover, E. L. (1992). A prognostic role for ceruloplasmin in the diagnosis of indolent and recurrent inflammation. J. Natl. Med. Assoc. 84, 781-784.

Nevitt, T., Ohrvik, H., and Thiele, D. J. (2012). Charting the travels of copper in eukaryotes from yeast to mammals. Biochim. Biophys. Acta 1823, 1580-1593. doi: 10.1016/j.bbamcr.2012.02.011

Newberne, P. M., Hunt, C. E., and Young, V. R. (1968). The role of diet and the reticuloendothelial system in the response of rats to Salmonella typhilmurium infection. Br. J. Exp. Pathol. 49, 448-457.

Nies, D. H., and Silver, S. (1995). Ion efflux systems involved in bacterial metal resistances. J. Ind. Microbiol. 14, 186-199. doi: 10.1007/BF01569902

Odermatt, A., Krapf, R., and Solioz, M. (1994). Induction of the putative copper ATPases, CopA and CopB, of Enterococcus hirae by $\mathrm{Ag}^{+}$and $\mathrm{Cu}_{2}^{+}$, and $\mathrm{Ag}^{+}$extrusion by CopB. Biochem. Biophys. Res. Commun. 202, 44-48. doi: 10.1006/bbrc.1994.1891

Odermatt, A., and Solioz, M. (1995). Two trans-acting metalloregulatory proteins controlling expression of the copper-ATPases of Enterococcus hirae. J. Biol. Chem. 270, 4349-4354. doi: 10.1074/jbc.270.9.4349

Osman, D., and Cavet, J. S. (2008). Copper homeostasis in bacteria. Adv. Appl. Microbiol. 65, 217-247. doi: 10.1016/S0065-2164(08)00608-4

Osman, D., and Cavet, J. S. (2011). Metal sensing in Salmonella: implications for pathogenesis. Adv. Microb. Physiol. 58, 175-232. doi: 10.1016/B978-0-12381043-4.00005-2

Osman, D., Waldron, K. J., Denton, H., Taylor, C. M., Grant, A. J., Mastroeni, P., et al. (2010). Copper homeostasis in Salmonella is atypical and copper-CueP is a major periplasmic metal complex. J. Biol. Chem. 285, 25259-25268. doi: 10.1074/jbc.M110.145953

Osterberg, R., Ligaarden, R., and Persson, D. (1979). Copper(I) complexes of penicillamine and glutathione. J. Inorg. Biochem. 10, 341-355. doi: 10.1016/S01620134(00)80200-7

Outten, C. E., and O'Halloran, T. V. (2001). Femtomolar sensitivity of metalloregulatory proteins controlling zinc homeostasis. Science 292, 2488-2492. doi: 10.1126/science. 1060331

Outten, F. W., Huffman, D. L., Hale, J. A., and O'Halloran, T. V. (2001). The independent cue and cus systems confer copper tolerance during aerobic and anaerobic growth in Escherichia coli. J. Biol. Chem. 276, 30670-30677. doi: 10.1074/jbc.M104122200

Outten, F. W., Outten, C. E., Hale, J., and O’Halloran, T. V. (2000). Transcriptional activation of an Escherichia coli copper efflux regulon by the chromosomal MerR homologue, cueR. J. Biol. Chem. 275, 31024-31029. doi: 10.1074/jbc.M006508200

Paulsen, I. T., Brown, M. H., and Skurray, R. A. (1996). Proton-dependent multidrug efflux systems. Microbiol. Rev. 60, 575-608.

Peariso, K., Huffman, D. L., Penner-Hahn, J. E., and O’Halloran, T. V. (2003). The PcoC copper resistance protein coordinates $\mathrm{Cu}(\mathrm{I})$ via novel S-methionine interactions. J. Am. Chem. Soc. 125, 342-343. doi: 10.1021/ja028935y

Pena, M. M., Lee, J., and Thiele, D. J. (1999). A delicate balance: homeostatic control of copper uptake and distribution. J. Nutr. 129, 1251-1260.

Petersen, C., and Moller, L. B. (2000). Control of copper homeostasis in Escherichia coli by a P-type ATPase, CopA, and a MerR-like transcriptional activator, CopR. Gene 261, 289-298. doi: 10.1016/S0378-1119(00)00509-6

Petris, M. J., Smith, K., Lee, J., and Thiele, D. J. (2003). Copper-stimulated endocytosis and degradation of the human copper transporter, hCtr1. J. Biol. Chem. 278, 9639-3646. doi: 10.1074/jbc.M209455200

Pontel, L. B., Audero, M. E., Espariz, M., Checa, S. K., and Soncini, F. C. (2007). GolS controls the response to gold by the hierarchical induction of Salmonellaspecific genes that include a CBA efflux-coding operon. Mol. Microbiol. 66, 814-825. doi: 10.1111/j.1365-2958.2007.05963.x

Pontel, L. B., and Soncini, F. C. (2009). Alternative periplasmic copper-resistance mechanisms in Gram negative bacteria. Mol. Microbiol. 73, 212-225. doi: 10.1111/j.1365-2958.2009.06763.x 
Portmann, R., Poulsen, K. R., Wimmer, R., and Solioz, M. (2006). CopY-like copper inducible repressors are putative 'winged helix' proteins. Biometals 19, 61-70. doi: 10.1007/s10534-005-5381-3

Prohaska, J. R., and Lukasewycz, O. A. (1990). Effects of copper deficiency on the immune system. Adv. Exp. Med. Biol. 262, 123-143. doi: 10.1007/978-1-46130553-8_11

Qin, Z., Konaniah, E. S., Neltner, B., Nemenoff, R. A., Hui, D. Y., and Weintraub, N. L. (2010). Participation of ATP7A in macrophage mediated oxidation of LDL. J. Lipid Res. 51, 1471-1477. doi: 10.1194/jlr.M003426

Rademacher, C., and Masepohl, B. (2012). Copper-responsive gene regulation in bacteria. Microbiology 158, 2451-2464. doi: 10.1099/mic.0.058487-0

Rauser, W. E. (1999). Structure and function of metal chelators produced by plants: the case for organic acids, amino acids, phytin, and metallothioneins. Cell Biochem. Biophys. 31, 19-48. doi: 10.1007/BF02738153

Rensing, C., Fan, B., Sharma, R., Mitra, B., and Rosen, B. P. (2000). CopA: an Escherichia coli $\mathrm{Cu}(\mathrm{I})$-translocating P-type ATPase. Proc. Natl. Acad. Sci. U.S.A. 97, 652-656. doi: 10.1073/pnas.97.2.652

Reyes-Jara, A., Latorre, M., Lopez, G., Bourgogne, A., Murray, B. E., Cambiazo, V., et al. (2010). Genome-wide transcriptome analysis of the adaptive response of Enterococcus faecalis to copper exposure. Biometals 23, 1105-1112. doi: 10.1007/s10534-010-9356-7

Roberts, S. A., Weichsel, A., Grass, G., Thakali, K., Hazzard, J. T., Tollin, G., et al. (2002). Crystal structure and electron transfer kinetics of CueO, a multicopper oxidase required for copper homeostasis in Escherichia coli. Proc. Natl. Acad. Sci. U.S.A. 99, 2766-2771. doi: 10.1073/pnas.052710499

Rowland, J. L., and Niederweis, M. (2012). Resistance mechanisms of Mycobacterium tuberculosis against phagosomal copper overload. Tuberculosis 92, 202-210. doi: 10.1016/j.tube.2011.12.006

Rowland, J. L., and Niederweis, M. (2013). A multicopper oxidase is required for copper resistance in Mycobacterium tuberculosis. J. Bacteriol. 195, 3724-3733. doi: 10.1128/JB.00546-13

Sandegren, L., Linkevicius, M., Lytsy, B., Melhus, A., and Andersson, D. I. (2012). Transfer of an Escherichia coli ST131 multiresistance cassette has created a Klebsiella pneumoniae-specific plasmid associated with a major nosocomial outbreak. J. Antimicrob. Chemother. 67, 74-83. doi: 10.1093/jac/dkr405

Shafeeq, S., Yesilkaya, H., Kloosterman, T. G., Narayanan, G., Wandel, M., Andrew, P. W., et al. (2011). The cop operon is required for copper homeostasis and contributes to virulence in Streptococcus pneumoniae. Mol. Microbiol. 81, 1255-1270. doi: 10.1111/j.1365-2958.2011.07758.x

Shi, J., Lindsay, W. P., Huckle, J. W., Morby, A. P., and Robinson, N. J. (1992). Cyanobacterial metallothionein gene expressed in Escherichia coli. Metalbinding properties of the expressed protein. FEBS Lett. 303, 159-163. doi: 10.1016/0014-5793(92)80509-F

Shoeb, E., Badar, U., Akhter, J., Shams, H., Sultana, M., and Ansari, M. A. (2012). Horizontal gene transfer of stress resistance genes through plasmid transport. World J. Microbiol. Biotechnol. 28, 1021-1025. doi: 10.1007/s11274-011-0900-6

Singh, S. K., Grass, G., Rensing, C., and Montfort, W. R. (2004). Cuprous oxidase activity of CueO from Escherichia coli. J. Bacteriol. 186, 7815-7817. doi: 10.1128/JB.186.22.7815-7817.2004

Smith, A. D., Botero, S., and Levander, O. A. (2008). Copper deficiency increases the virulence of amyocarditic and myocarditic strains of coxsackievirus B3 in mice. J. Nutr. 138, 849-855.

Stadtman, E. R. (2006). Protein oxidation and aging. Free Radic. Res. 40, 1250-1258. doi: 10.1080/10715760600918142

Stoyanov, J. V., Hobman, J. L., and Brown, N. L. (2001). CueR (YbbI) of Escherichia coli is a MerR family regulator controlling expression of the copper exporter CopA. Mol. Microbiol. 39, 502-511. doi: 10.1046/j.1365-2958.2001. 02264.x

Stoyanov, J. V., Magnani, D., and Solioz, M. (2003). Measurement of cytoplasmic copper, silver, and gold with a lux biosensor shows copper and silver, but not gold, efflux by the CopA ATPase of Escherichia coli. FEBS Lett. 546, 391-394. doi: 10.1016/S0014-5793(03)00640-9

Strausak, D., and Solioz, M. (1997). CopY is a copper-inducible repressor of the Enterococcus hirae copper ATPases. J. Biol. Chem. 272, 8932-8936. doi: 10.1074/jbc. 272.14 .8932

Sullivan, J. L., and Ochs, H. D. (1978). Copper deficiency and the immune system. Lancet 2, 686. doi: 10.1016/S0140-6736(78)92806-4

Tanzi, R. E., Petrukhin, K., Chernov, I., Pellequer, J. L., Wasco, W., Ross, B., et al. (1993). The Wilson disease gene is a copper transporting ATPase with homology to the Menkes disease gene. Nat. Genet. 5, 344-350. doi: 10.1038/ng1293-344
Teitzel, G. M., Geddie, A., De Long, S. K., Kirisits, M. J., Whiteley, M., and Parsek, M. R. (2006). Survival and growth in the presence of elevated copper: transcriptional profiling of copper-stressed Pseudomonas aeruginosa. J. Bacteriol. 188, 7242-7256. doi: 10.1128/JB.00837-06

Tetaz, T. J., and Luke, R. K. (1983). Plasmid-controlled resistance to copper in Escherichia coli. J. Bacteriol. 154, 1263-1268.

Thaden, J. T., Lory, S., and Gardner, T. S. (2010). Quorum-sensing regulation of a copper toxicity system in Pseudomonas aeruginosa. J. Bacteriol. 192, 2557-2568. doi: 10.1128/JB.01528-09

Thirumoorthy, N., Shyam Sunder, A., Manisenthil Kumar, K., Senthil Kumar, M., Ganesh, G., and Chatterjee, M. (2011). A review of metallothionein isoforms and their role in pathophysiology. World J. Surg. Oncol. 9, 54. doi: 10.1186/14777819-9-54

Trigui, H., Dudyk, P., Sum, J., Shuman, H. A., and Faucher, S. P. (2013). Analysis of the transcriptome of Legionella pneumophila hfq mutant reveals a new mobile genetic element. Microbiology 159(Pt 8), 1649-1660. doi: 10.1099/mic. 0.067983-0

Tufft, L. S., Nockels, C. F., and Fettman, M. J. (1988). Effects of Escherichia coli on iron, copper, and zinc metabolism in chicks. Avian Dis. 32, 779-786. doi: $10.2307 / 1590998$

Vancampen, D. R., and Mitchell, E. A. (1965). Absorption of Cu-64, Zn-65, Mo99, and Fe-59 from ligated segments of the rat gastrointestinal tract. J. Nutr. 86, $120-124$.

Vats, N., and Lee, S. F. (2001). Characterization of a copper-transport operon, copYAZ, from Streptococcus mutans. Microbiology 147, 653-662.

Voloudakis, A. E., Bender, C. L., and Cooksey, D. A. (1993). Similarity between copper resistance genes from Xanthomonas campestris and Pseudomonas syringae. Appl. Environ. Microbiol. 59, 1627-1634.

von Rozycki, T., and Nies, D. H. (2009). Cupriavidus metallidurans: evolution of a metal-resistant bacterium. Antonie Van Leeuwenhoek 96, 115-139. doi: 10.1007/s10482-008-9284-5

Voruganti, V. S., Klein, G. L., Lu, H. X., Thomas, S., Freeland-Graves, J. H., and Herndon, D. N. (2005). Impaired zinc and copper status in children with burn injuries: need to reassess nutritional requirements. Burns 31, 711-716. doi: 10.1016/j.burns.2005.04.026

Vulpe, C., Levinson, B., Whitney, S., Packman, S., and Gitschier, J. (1993). Isolation of a candidate gene for Menkes disease and evidence that it encodes a coppertransporting ATPase. Nat. Genet. 3, 7-13. doi: 10.1038/ng0193-7

Vulpe, C. D., Kuo, Y. M., Murphy, T. L., Cowley, L., Askwith, C., Libina, N., et al. (1999). Hephaestin, a ceruloplasmin homologue implicated in intestinal iron transport, is defective in the sla mouse. Nat. Genet. 21, 195-199. doi: $10.1038 / 5979$

Wagner, D., Maser, J., Lai, B., Cai, Z., Barry, C. E. 3rd., Honer Zu Bentrup, K., et al. (2005). Elemental analysis of Mycobacterium avium-, Mycobacterium tuberculosis-, and Mycobacterium smegmatis-containing phagosomes indicates pathogen-induced microenvironments within the host cell's endosomal system. J. Immunol. 174, 1491-1500.

Waidner, B., Melchers, K., Stahler, F. N., Kist, M., and Bereswill, S. (2005). The Helicobacter pylori CrdRS two-component regulation system (HP1364/HP1365) is required for copper-mediated induction of the copper resistance determinant CrdA. J. Bacteriol. 187, 4683-4688. doi: 10.1128/JB.187.13.4683-4688.2005

Wang, Y., Hodgkinson, V., Zhu, S., Weisman, G. A., and Petris, M. J. (2011). Advances in the understanding of mammalian copper transporters. Adv. Nutr. 2, 129-137. doi: 10.3945/an.110.000273

Ward, S. K., Hoye, E. A., and Talaat, A. M. (2008). The global responses of Mycobacterium tuberculosis to physiological levels of copper. J. Bacteriol. 190, 2939-2946. doi: 10.1128/JB.01847-07

White, C., Lee, J., Kambe, T., Fritsche, K., and Petris, M. J. (2009). A role for the ATP7A copper-transporting ATPase in macrophage bactericidal activity. J. Biol. Chem. 284, 33949-33956. doi: 10.1074/jbc.M109.070201

Williams, J. R., Morgan, A. G., Rouch, D. A., Brown, N. L., and Lee, B. T. (1993). Copper-resistant enteric bacteria from United Kingdom and Australian piggeries. Appl. Environ. Microbiol. 59, 2531-2537.

Wolschendorf, F., Ackart, D., Shrestha, T. B., Hascall-Dove, L., Nolan, S., Lamichhane, G., et al. (2011). Copper resistance is essential for virulence of Mycobacterium tuberculosis. Proc. Natl. Acad. Sci. U.S.A. 108, 1621-1626. doi: 10.1073/pnas. 1009261108

Xu, F. F., and Imlay, J. A. (2012). Silver(I), mercury(II), cadmium(II), and zinc(II) target exposed enzymic iron-sulfur clusters when they toxify Escherichia coli. Appl. Environ. Microbiol. 78, 3614-3621. doi: 10.1128/AEM.07368-11 
Xue, Y., Davis, A. V., Balakrishnan, G., Stasser, J. P., Staehlin, B. M., Focia, P., et al. (2008). Cu(I) recognition via cation-pi and methionine interactions in CusF. Nat. Chem. Biol. 4, 107-109. doi: 10.1038/nchembio.2007.57

Yamamoto, K., and Ishihama, A. (2005). Transcriptional response of Escherichia coli to external copper. Mol. Microbiol. 56, 215-227. doi: 10.1111/j.13652958.2005.04532.x

Yamamoto, K., and Ishihama, A. (2006). Characterization of copper-inducible promoters regulated by CpxA/CpxR in Escherichia coli. Biosci. Biotechnol. Biochem. 70, 1688-1695. doi: 10.1271/bbb.60024

Yoshida, Y., Furuta, S., and Niki, E. (1993). Effects of metal chelating agents on the oxidation of lipids induced by copper and iron. Biochim. Biophys. Acta 1210, 81-88. doi: 10.1016/0005-2760(93)90052-B

Zhou, B., and Gitschier, J. (1997). hCTR1: a human gene for copper uptake identified by complementation in yeast. Proc. Natl. Acad. Sci. U.S.A. 94, 7481-7486. doi: 10.1073/pnas.94.14.7481

Zimmermann, M., Udagedara, S. R., Sze, C. M., Ryan, T. M., Howlett, G. J., Xiao, Z., et al. (2012). PcoE-a metal sponge expressed to the periplasm of copper resistance Escherichia coli. Implication of its function role in copper resistance. J. Inorg. Biochem. 115, 186-197. doi: 10.1016/j.jinorgbio.2012.04.009
Conflict of Interest Statement: The authors declare that the research was conducted in the absence of any commercial or financial relationships that could be construed as a potential conflict of interest.

Received: 01 October 2013; accepted: 06 January 2014; published online: 03 February 2014.

Citation: Chaturvedi KS and Henderson JP (2014) Pathogenic adaptations to hostderived antibacterial copper. Front. Cell. Infect. Microbiol. 4:3. doi: 10.3389/fcimb. 2014.00003

This article was submitted to the journal Frontiers in Cellular and Infection Microbiology.

Copyright (c) 2014 Chaturvedi and Henderson. This is an open-access article distributed under the terms of the Creative Commons Attribution License (CC BY). The use, distribution or reproduction in other forums is permitted, provided the original author(s) or licensor are credited and that the original publication in this journal is cited, in accordance with accepted academic practice. No use, distribution or reproduction is permitted which does not comply with these terms. 